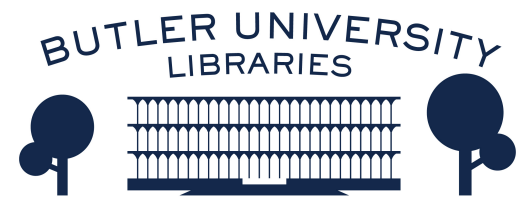

Journal of Hindu-Christian Studies

Volume 32 Discussion of Nathaniel Roberts, To

Be Cared For: The Power of Conversion and

Article 17

Foreignness of Belonging to An Indian Slum.

2019

\title{
Book Review: Infinite Paths to Infinite Reality: Sri Ramakrishna \& Cross-Cultural Philosophy of Religion
}

\author{
Patrick Beldio \\ Bard Early College-DC
}

Follow this and additional works at: https://digitalcommons.butler.edu/jhcs

\section{Recommended Citation}

Beldio, Patrick (2019) "Book Review: Infinite Paths to Infinite Reality: Sri Ramakrishna \& Cross-Cultural Philosophy of Religion," Journal of Hindu-Christian Studies: Vol. 32, Article 17.

Available at: https://doi.org/10.7825/2164-6279.1743

The Journal of Hindu-Christian Studies is a publication of the Society for Hindu-Christian Studies. The digital version is made available by Digital Commons @ Butler University. For questions about the Journal or the Society, please contact cbauman@butler.edu. For more information about Digital Commons @ Butler University, please contact digitalscholarship@butler.edu. 
be a source of grace in dialogues about God (324). The stuff of life calls for patience and attention, study and reflection-in a word: learning.
Michelle Voss Roberts

Emmanuel College of Victoria University in the University of Toronto

\section{Infinite Paths to Infinite Reality: Sri Ramakrishna \& Cross-Cultural Philosophy of Religion. By Ayon Maharaj. New York: Oxford University Press, 2018. xii +350 pages.}

IN this compelling text, Ayon Maharaj critically explores the implications of the life and teachings of Sri Ramakrishna (1836-1886) on contemporary theories of divine infinitude, religious pluralism, mystical experience, and theodicy. This monk of the Ramakrishna Order and scholar of cross-cultural philosophy battles misunderstandings about the Master both within and outside the academy. Maharaj's bright philosophical mind and methodically researched efforts shed new light on what he calls Sri Ramakrishna's Vijñāna Vedānta, a path of "intimate knowledge" that both ascends to spiritual union with the Impersonal Absolute, yet descends in equal measure to knowledge, selfless service, and devotion to the Personal Sakti, who is present as the dynamic play (lïlâ) of all forms.

Maharaj primarily uses The Gospel of Sri Ramakrishna and the biography Sri Sri Lilaprasanga for philosophical and theological exegesis, both of which were written by close disciples. He places these in critical correlation with many relevant western philosophers and theologians. Maharaj's book is divided into four parts. Part I, "The Infinitude of God," is chapters 1 and 2 in which Maharaj argues for Vijñanna Vedānta as the lens through which we should interpret Sri Ramakrishna's teachings, which points to his understanding of divine infinitude that is both personal and impersonal, immanent and transcendent, theistic and non-theistic. He then brings his interpretation into dialogue with western conceptions of divine infinitude, including Nicholas of Cusa and his idea of the coincidentia oppositorum, Benedikt Paul Göcke and his notion of "paraconsistent logic," and Jean Luc Marion's thought on "conceptual idolatry."

Part II, "Religious Pluralism," which includes chapters 3 and 4, builds upon his framework of Vijñāna Vedānta to describe the Master's latent theory of religious pluralism. Maharaj argues that both theistic and nontheistic religions can be seen in this theory as equally salvific paths. Salvation is "Godrealization," a term that Maharaj provocatively keeps undetermined but also limits in ways that require more critical investigation. His engagement with John Hick's early and later view of religious pluralism rounds out this part of the text. Hick's early view relies upon Sri Aurobindo's "logic of the infinite," which Maharaj argues is akin to Sri Ramakrishna's (since indeed, Sri Aurobindo was influenced by the Master, though important differences could be brought forward). Maharaj argues that Hick mistakenly abandons his Aurobindonian theory for a quasi-Kantian one since it fails to grant full ontological reality to each world religion's conception of divinity, whether theistic or non-theistic. 
Chapters 5 and 6 comprise Part III, "Mystical Experience," which tries to penetrate the supra-rational basis of religious truth claims about Ultimate Reality. Maharaj describes a new paradigm of mystical experience based on Vijñāna Vedānta that he argues is more inclusive of all religions than other paradigms. Sri Ramakrishna's claims to "God-realization" across traditions (in Hindu theistic and nontheistic paths, Christianity, Islam, and the Brāhmo Samāj) convince him that each is a different ontologically real manifestation of the Infinite One behind the Many. Maharaj calls this a "manifestationist" approach that he argues affirms the world's religions better than the "perennialist" and "constructivist" approaches, though these too have their strengths. He deepens this critical reflection by engaging current philosophers who either dismiss or accept mystical experience as a valid source of truth. Supported by the work of Robert Oakes, Maharaj claims that self-authenticating experiences of God are logically possible in light of Sri Ramakrishna and that the Master's teaching can bolster current thinkers like Jerome Gellman and William Wainwright who defend the ability to cross-check mystical experience.

Maharaj interprets Sri Ramakrishna's teaching stories that have direct relevance to theories of mystical experience in a curious way. One salient parable tells of a man who watches different people who mistake the different colors of a chameleon on a tree as its only color. The man under the tree, however, knows the truth. Maharaj argues that this parable teaches that not even the vijñāni "can experience the whole of the Infinite God" though the man under the tree clearly represents someone who can (144). This is where a further refinement of the term "GodRealization" would be welcome since many teachers influenced by Sri Ramakrishna or that can be arguably compared to the Bengali Master define God-realization as beyond "experience" and precisely the state of being the whole of Infinite God where the dualities of personal and impersonal divine aspects find perfect balance. These teachers arguably include Sri Nisargadatta in I Am That, Meher Baba in God Speaks, and Sri Aurobindo in The Life Divine, among others.

Chapters 7 and 8, which make up the last part entitled "The Problem of Evil," utilize Sri Ramakrishna's vijñāna-based teaching to face contemporary thinkers who doubt the existence of God because of evil and suffering in the world. Maharaj grounds his argument in what he calls Sri Ramakrishna's "skeptical theism"; the view that human intelligence is incapable of following and judging the cause and effect of so-called evil in the world. The theodicy that Maharaj constructs is one in which the divine uses evil, "according to Sri Ramakrishna," 'in order to create saints"' over many lifetimes (244). In fact, in light of vijñāna, Maharaj argues, "God Himself sports in the form of both evildoers and their victims, so the problem of evil-which generally presupposes a difference between God and His suffering creatures-does not even arise" (245). These provocative chapters are significant in my view as they provide very helpful theoretical foundations not only for Sri Ramakrishna but also for the theodicies of others, including the Mother and Sri Aurobindo and Meher Baba, who mirror Sri Ramakrishna in undeniable ways. Maharaj continues his investigation of the problem of evil comparing Sri Ramakrishna with John Hick. Hick provides Maharaj with ways to bring out what he considers Sri Ramakrishna's more advantageous teaching on universal salvation; that it is the destiny of all souls, no matter the external appearances of evil, to 
reach the goal of God-realization--because of, not in spite of such oppositions.

We should be grateful for Maharaj's work to construct such a stable cross-cultural intellectual basis from which to reinterpret Sri Ramakrishna's contemporary relevance. Teachers and students of religious studies, comparative theology, interreligious dialogue, and contemporary analytic philosophy will be drawn to this text; and owing to what I consider Maharaj's devotion-as-scholarship, they will be enticed to encounter more deeply the matchless Sri Ramakrishna.

Patrick Beldio

Bard Early College-DC

\section{Christianity in India: Conversion, Community Development, and Religious Freedom. Edited by Rebecca Samuel Shah and Joel Carpenter. Minneapolis: Fortress Press, 2018, xix +311 pages.}

REVIEWING edited volumes is always difficult, and even more so in the case of this particular volume, both because its theme is a somewhat general and loosely-imposed one, and because the quality of its chapters varies considerably. To some extent, the chapters' varied quality is a function of the fact that they emerged from a workshop in India that brought seasoned India scholars together with other scholars who were encountering India academically (and maybe even personally) for the very first time. Another challenge is the range of disciplines represented in the volume. While interdisciplinarity is a generally good thing, in this case the disciplinary range includes both openly partisan Christian theological/ missiological essays, on the one hand, and, on the other, essays striving for impartiality and conforming more closely to secular norms of scholarship. There is of course nothing inherently wrong with the juxtaposition of such disparate disciplines, but the oscillation between them can be somewhat disorienting. At the very least, this juxtaposition requires that I acknowledge the fact I work more comfortably in that latter, more secular scholarly vein, which may prejudice my appreciation of essays in the former. Caveat lector.
While not all of the volume's chapters contribute to it equally, the primary focus of the book is on the contributions of Christians to Indian society in the context of increasing anti-Christian discrimination and violence. A further argument-implicit throughout, but stated explicitly in the Introduction and then more fully in Chapter 11 (by political scientist Paul S. Rowe)-is that India stands to lose the important contribution of Christians to civil society if anti-Christian persecution should continue or increase. To that end, the volume opens with a strong chapter by Rebecca Samuel Shah, who reviews the history of Hindu nationalism and provides both an overview and critique of its central obsessions (e.g., conversion, inducement, the unity of Hinduism) with special attention to their ramifications for India's Christians. This overview is so strong, in fact, that one wishes other authors in the volume hadn't felt the need, as several of them did, to clutter their own essays with introductory (and far more general/unsatisfying) overviews covering the same territory.

In the second chapter, Sean Doyle provides a biographical essay on the famous high-caste Hindu convert to Christianity, Lakshmibai Tilak (1868-1936). Along with her 